\title{
Beyond Values and Interests: The Anglo-America Special Relationship during the Syrian Conflict
}

\author{
Justin Gibbins ${ }^{1}$, Shaghayegh Rostampour ${ }^{2}$ \\ ${ }^{1}$ Zayed University, Dubai, UAE \\ ${ }^{2}$ Brandeis University, Waltham, Massachusetts, USA \\ Email: Justin.Gibbins@zu.ac.ae, Shrostampour@brandeis.edu
}

How to cite this paper: Gibbins, J., \& Rostampour, S. (2019). Beyond Values and Interests: The Anglo-America Special Relationship during the Syrian Conflict. Open Journal of Political Science, 9, 72-106. https://doi.org/10.4236/ojps.2019.91005

Received: November 26, 2018 Accepted: December 26, 2018 Published: December 29, 2018

Copyright (c) 2019 by authors and Scientific Research Publishing Inc. This work is licensed under the Creative Commons Attribution International License (CC BY 4.0).

http://creativecommons.org/licenses/by/4.0/

\begin{abstract}
This paper attempts to reveal how intervention in international conflicts (re) constructs the Anglo-American Special Relationship (AASR). To do this, this article uses Syria as a case study. Analyzing parliamentary debates, presidential/prime ministerial speeches and formal official addresses, it offers a discursive constructivist analysis of key British and US political spokespeople. We argue that historically embedded values and interests stemming from unity forged by World War Two have taken on new meanings: the AASR being constructed by both normative and strategic cultures. The former, we argue, continues to forge a common alliance between the US and Britain, while the latter produces notable tensions between the two states.
\end{abstract}

\section{Keywords}

Anglo-American, Special Relationship, Discourse, Intervention, Conflict

\section{Introduction}

At various times in its protracted history, the Anglo-American Special Relationship ${ }^{1}$ has waxed and waned in its potency since Winston Churchill's first usage. Coined during the early glow of the Cold War, its various metamorphoses have continued to emit a positive albeit frequently faint flicker. In the late 1960s, the Wilson-Johnson affiliation defined the relationship as "close" with an economically burgeoning West Germany functioning as the most fa-

${ }^{1}$ The Anglo-American Special Relationship (AASR), the Special Relationship and the Anglo-American Alliance are all used synonymously. 
vored European source of Atlantic interest coupled with Anglo-American ${ }^{2} \log$ gerheads over the Vietnam War (Colman, 2004). The Heath-Nixon early-seventies also saw a continuation of the transatlantic cooling with an unsentimental "natural" relationship defining a Europeanist Britain, shorn of its past transatlantic bonds, so much so that Henry Kissinger was to describe Nixon later on as feeling like a "jilted lover" (Ellis, 2009: p. 174). The Thatcher-Reagan years produced, by contrast, an "extraordinary alliance" (Reynolds, 1985-6: p. 1) with a fusion not merely of Anglo-American interests, namely the pursuit of anticommunism, but also a conceptual coalition championing the logic of economic liberalism. The 1990s further continued the spiritual union with Blair and Clinton "... joined at the hip as energetic practitioners of 'Third Way' politics” (Campbell \& Rockman, 2001: p. 36) whilst the Bush-Blair rapport forged in the wake of the terrorist attacks of 11 September 2001 seemed to shift the Special Relationship from an ideological accord to a much deeper defense of values (Marsh, 2005); precious creeds that were under assault. Over a decade later, the then Secretary of State, John Kerry, in the wake of the British parliamentary no vote to support American-led military action in Syria (see, for example, Strong, 2015; Kaarbo \& Kenealy, 2016), framed the relationship in terms of ".. an alliance of values, values of freedom, of maintaining international peace and security, of making sure that we live in a rules-based world" (Kerry, 2013, 9 September).

Its constant articulation, therefore, suggests the AASR lives on. It absorbs elements of the old and yet also seems to take on new faces. Crises are events that give meaning to these new faces by galvanizing state representatives to articulate their views and ideas. Such watershed moments, called critical junctures, can be defined as "... perceived crisis situations occurring from complete policy failures, but also triggered by external events" (Marcussen et al., 1999: p. 616). This paper utilizes the Syrian war as the contemporary critical juncture of choice. The argument proceeds in the following manner. The following section outlines how the AASR has been commonly configured within the existing literature. The methodological section examines the empirical tool of predicate analysis along with an explanation of the sources employed and choice of case study. The subsequent empirical parts present and discuss the findings in four distinct ways: as a cultural, functional, normative and strategic relationship. Each section contains an explanation of the relationship and is concluded by a table synthesizing the outcomes. The final section highlights how the Special Relationship has gone beyond traditional invocations of values and interests. Notable differences as well as similarities between how the two states view one another are underscored as well as the consequent impact this has on reconfiguring the AASR.

${ }^{2}$ Anglo-, British and UK are neither unproblematic nor identical terms. However, for the purposes of this paper, they are all used to define the United Kingdom as a political, national and historical entity. 


\section{Anglo-American Special Relations: Post-World War II Foreign Policy}

Despite special relationships designating that some states' associations are different from the norm, specialness is not actually peripheral within international relations. Germany and Israel (Oppermann \& Hansel, 2016), the USA and Canada (Dickey, 1975), India and Japan (Mishra, 2016), and Russia and China (Savic, 2016) are a few examples that emphasize the fact that over 50 current relationships can be categorized as special (Harnisch et al., 2015) ${ }^{3}$ Specialness indicates exceptionalism: that two states are linked in such a way that is noticeably different to the manner they conduct their relations with other states. More specifically, special relations have been defined as:

... durable and exclusive bilateral relations between autonomous polities that are based on mutual expectations of preferential treatment by its members and outsiders as well as regular entanglement of some (external) governance functions. (Harnisch, 2017, April 13)

Durability and exclusivity inevitably find themselves lodged within the twin pillars of values and interests: that special relationships have been solidified by a cultural sense of affinity or that common interests and goals have forged a symbiotic closeness. Within the AASR, Dobson and Marsh have characterized these pillars as the schools of sentiment and interests that fit into the long-standing friction between idealism and realism within international relations theory (Dobson \& Marsh, 2013). Danchev has also defined the relationship as evangelical, functional and terminal. For evangelists, “... specialness was like the scriptures" (Danchev, 1996: p. 738) promulgated early on by the Evangelist-in-Chief, Winston Churchill. The Sinews of Peace speech, delivered in Fulton, Missouri on March 5, 1946, produced early consanguinity with appeals to "fraternal association" and "kindred systems of society" (Churchill, 1946). Non-material bonds between the US and Britain have included traditions, experiences and habits (Allen, 1985); culture (Coker, 1992); a shared history with fundamental freedoms and rights (Brown, 2008 in Wallace and Phillips, 2009); and language that created a “... world-wide Anglophone imperial community" (Judt, 2005: p. 160). As Henry Kissinger highlighted in an address at Chatham House commemorating the bicentenary of the office of Foreign Secretary:

Both Britain and America have learned that whatever their histories, their futures are part of the common destiny of freedom. Experience has taught that moral idealism and geographical insight are not alternative but complementary, our civilisation may not survive unless we possess both in full measure. (1982, $p$. 157)

Functionalism, or how the Special Relationship is best explained by common interests, has perhaps been the more dominant means of understanding the al-

${ }^{3}$ Harnisch et al. include essays on the United Kingdom and Arab monarchies, Australia and the US, Germany and Tunisia, China and Latin America, China and socialist states, India and China, Germany and the US, France and Sweden, Germany and France, Russia and Ukraine as well as special relationships between the members of the Collective Security Treaty Organization. 
liance. George Orwell, writing just two years after World War Two, iterated US supremacy and the epiphenomenal status it placed on post-war Britain:

We are no longer strong enough to stand alone, and if we fail to bring a western European union into being, we shall be obliged, in the long run, to subordinate our policy to that of one Great Power or the other. And in spite of all the fashionable chatter of the moment, everyone knows in his heart that we should choose America. (2000, p. 398)

Cold War security issues galvanized cooperation in nuclear, military and intelligence sharing. Reynolds has clarified four particular policy areas of common interest: the consultative relationship of the two states' bureaucracies, the intelligence axis created during World War Two, the close naval contact based on common protection of the north Atlantic and the nuclear alliance centered on the "missiles for bases" agreement which enabled the UK to adopt the submarine-based ballistic missile Polaris after the Kennedy-Macmillan 1962 Nassau Agreement (Reynolds, 1988-9). Aldrich similarly highlights the necessity of building a Western intelligence community (1998) and the Special Relationship is both shaper of and shaped by this security obligation. In addition, important rifts between the US and UK, most notably the Suez Crisis in 1956 which underscored Britain's weakness and has been adroitly described as symbolic of the identity clash between "the coming" and "the going" as the US became increasingly zealous to adopt a leadership role and Britain equally unwilling to let go of theirs (BiallyMattern, 2004). Further frustration centered on Vietnam and specifically unsought for British advice coupled with an unwillingness to send troops prompting President Johnson to say to Prime Minister Wilson in a phone call, "I won't tell you how to run Malaysia and you don't tell us how to run Vietnam" (Ellis, 2004: p. 50). Common interests as well as conflicting interests are an obvious means to understanding the rapprochement and ruptures that make up the history of the AASR.

The terminal school highlights the blunt reality of "endism" (Danchev, 1996: p. 740). The AASR was merely a British sleight of hand, “... a 'tradition' invented as a tool of diplomacy" (Reynolds, 1985-6: p. 2) which might “... somehow allow the English ghost to pass into a new and vigorous body" (Hitchens, 1990: p. 24) and rescue a Britain struggling to see in the post-imperial dark. What was special is "Special no more" (Dickie, 1994) and the ruptures of Suez and Vietnam, and the go-it-aloneness of the post-Cold War American hyper-state have resigned the AASR to a nostalgic place in the past, not in the present let alone future. In addition, some scholarship has configured the relationship as "Lazarus like" (Marsh \& Baylis, 2006) for its continuities in bridging a Transatlantic-European divide. Others have underscored the path dependent nature of the AASR in which intelligence, nuclear and military matters have become institutionalized (Xu, 2016; Schmidt, 2005).

\section{Methodology}

The fact that the literature points to the importance of values and interests in de- 
fining the AASR is understandable. Values and interests are arguably the fundamentals of how all states articulate their foreign relations. However, it is not our argument that values and interests are of no importance in studying the Anglo-American alliance. Instead, we argue that case study of the Syrian conflict reveals that such rudiments have been reformulated. Common appeals to the tenets of culture, language, history etc. as well as the realist/materialist interest-based readings of the alliance are not dominant articulations within the Syria debates. Instead, we claim that the relationship is best realized through two principal configurations. The first is normativism. Normativism focuses on the power of norms and normative structures. Normative structures are the focus of the constructivist approach, which instead of highlighting the role of material factors on the dynamics of international relations, instead privileges ...

... how structures also are defined by collectively held ideas such as knowledge, rules, beliefs, and norms that not only constrain actors, but also construct categories of meaning, constitute their identities and interests, and define standards of appropriate conduct. (Baylis, Smith, \& Owens, 2014: p. 419)

Normativism has more specifically been located within debates over the European Union with the construction of Normative Power Europe and the EU operating as a non-material, ideational actor (Manners, 2002). As Rosencrance has argued:

Europe's attainment is normative rather than empirical ... It is perhaps a paradox to note that the continent which once ruled the world through the physical impositions of imperialism is now coming to set world standards in normative terms. (Rosencrance, 1998: p. 22, in Manners, 2002: p. 238)

As an ideational form of power, Manners has argued how it should be primarily seen as legitimate and coherent, with practices that are seen to be sound and non-contradictory; it should be persuasive with constructive engagement, the institutionalization of relations and the backing of dialogue between actors; and it must be socializing in that its impact must include socialization, partnership, and ownership (Manners, 2009). Normativism embodies a certain worldliness and engenders the importance of a behavioral framework shaped through political institutions, moral norms, shared markets or cultural affinities. It also implies a broader attachment to special obligations (see, for example, Bukovansky, Clark, Eckersley, Price, Reus-Smit, \& Wheeler, 2012). The US is the natural orchestrator of global responsibility and governance. As Secretary of State Madeline Albright stated in a television interview in 1998, "we are the indispensable nation. We stand tall and we see further than other countries into the future" (1998, February 19). In fact, states, it has been argued, function as moral agents but differ in their capacities which impact on their ability to achieve responsibility (Erskine, 2003: p. 34, in Bukovansky et al., p. 65-6). More specifically, we have taken normative culture to include three separate but linked categories based on the empirical findings. The first is humanitarianism. This includes how each state views the other as an agent focusing on human security rather than state security. References included in this grouping refer to "aid", "donor", 
"support", "assistance", "airdrops", and the like. The second configuration is multilateralism. Multilateralist orientations concentrate of addressing the conflict through coalition-building, cooperation, alliances, and allies. Finally, there is institutionalism. This final normative structure highlights the important role of institutions which reference the United Nations, The European Union, and the North Atlantic Treaty Organization in their abilities to foster resolution.

The second primary configuration that defines the AASR is strategic culture. Gray has provided the following definition:

Culture or cultures comprises the persisting (though not eternal) socially transmitted ideas, attitudes, traditions, habits of mind, and preferred methods of operation that are more or less specific to a particular geographically based security community that has had a necessarily unique historical experience. (Gray, 1999: p. 51)

A strategic culture encompasses the beliefs, attitudes, and norms towards the use of force (Chappell, 2009) and necessitates the reliance or non-reliance on military strength and a desire to engage militarily to protect the national interests or values of a state. Strategic cultures can change, such as postwar Germany and Japan, or they might be seen to symbolize and dictate the very essence of the state, such as North Korea. A militarist culture may take the form of predatory capitalist states in the Marxist critique, militarist social structures and ideology which condition bellicose behavior, psycho-cultural explanations that argue that some individuals and political leaders may have more "war-proneness" than others and even a pessimistic belief in human nature that simply locks human and consequent political behavior into a pattern of aggression (Skjelsbaek, 1979). We define the concept as the willingness to utilize military responses-be it air strikes, combat deployment or any other armed involvement-to achieve preferred political outcomes. That is, strategic culture is reflective of a certain behavior that strategizes and therefore employs a military response.

The concepts of normative and strategic culture are utilized because our interpretive, inductive reading of language patterns has produced a noticeable number of references to both concepts. That is, the manner in which each state views the other is dominated by these two categories. The US and UK representations and legitimizations of their roles informs us of the relationship between the two states. To arrive at these representations, we examine the language of prominent political spokespeople. We also take it that prominent spokespeople, or official discourses, are closest to the instruments of policy; i.e. party elites, "have always been major vehicles for the transmission of ideas" (Marcussen et al., 1999: p. 615). What party elites say and write are tied to the perceptions they have of states. Representatives of the political establishment, therefore, possess a triple role: to coin a phrase, they function as windows into the political soul; they formulate ideas about what meaning relationships have, in this study the UK, the USA as well as other international actors; and finally, they are simultaneously constrained by a pre-existing structure within which their ideas contain a certain resonance for the electorate. 
The various classifications which make up the AASR are derived through predicate analysis (see, for example, Doty, 1993; Milliken, 1999; Åhäll \& Berg, 2013). Predicate analysis "focuses on the language practices of predication-the verbs, adverbs and adjectives that attach to nouns" (Milliken, 1999: p. 232). As such, the objects, in this case the UK, US and other related state or non-state actors, are imbued with certain characteristics and qualities that have meaning. Predicates are formulated by asking what nouns, verbs, adjectives and adverbs are used and how they can be grouped to give a dominant representation of the state in question. A careful reading of the material produces commonly articulated predicates that can be grouped together as discourses. These representations shed light on the condition of the Special Relationship.

The corpus of speeches includes House of Commons and House of Lords debates, presidential/prime ministerial speeches and formal addresses by foreign secretaries, secretaries of state and other officials at the departments of state and defense have all been utilized from official websites and sources. The search criteria involved using the key word "Syria and ..." coupled with the "UK", "Britain", "US", "USA", "America”, and "Anglo-American". In total, 96 references by British spokespeople with reference to the United States, and 47 references by American spokespeople with reference to Britain, were discovered exclusively within the context of the Syrian conflict. The search focused on references from March 2011, when the Syrian conflict started, up to January 2016, when US President Barack Obama formally left office. Suffice to say, not all spokespeople possess the same degree of importance within political circles. It is obvious that the level of prominence of political spokespeople contributes to their ability to shape and inform the debate over how the Anglo-American alliance is configured. From the British perspective, what the member of the Cabinet says might be understandably seen as more significant than that of a backbencher. Equally as well, what the US Secretary of State announces is more influential than that of a representative of Congress. Nonetheless, we are predominantly concerned with how elites from one state have configured the other, rather than on who has said what.

Each quotation appearing in the tables are the references relating to the sources as they are listed in Appendix 1 and Appendix 2. Appendix 1 consists of British spokespeople's perceptions of the USA and Appendix 2 contains American political figures' views of Britain. All sources in the appendices are listed chronologically with most recent entries first.

Two further criteria were employed. First, as discourses operate as patterns of language, several references are required to exist in order to qualify as a discourse. Discourses built by many references are important as they present a dominant discourse. However, when single references could not be linked to other references in order to constitute a discourse, these were excluded. Secondly, only referents specifically making claims about what each state is and does have been included. As such, our study excludes many random references that tell us little 
about how one state perceives the other. As such, it is accepted that states continue to function as the most important actors in the international system and the Special Relationship can be understood via a discursive reading of the representatives of the two states to reveal patterns of co-dependency and divergence.

A final methodological issue concerns the choice of case study. There are several reasons for our focus on the Syrian conflict. Firstly, António Guterres, the then UN High Commissioner for Refugees, stated that the Syrian crisis "has become the biggest humanitarian emergency of our era" (UNHCR, 2015) with approximately six million internally displaced people, nearly five million seeking refuge outside the country and almost half a million deaths in the conflict $(\mathrm{Hu}-$ man Rights Watch, 2018). Secondly, with a host of actors both domestic and foreign, a grisly enemy in the form of the so-called Islamic State of Iraq and Syria, an exasperating body count coupled with biblical-sized migrations of people, and the lack of any unifying remedy, the conflict has become one of the defining crises of the modern world. Cold War tensions loom with Russia's Ambassador to the United Nations announcing in October 2016 that relations with the US were probably the worst since 1973 (Sengupta, 2016). Thirdly, Syria functions as a political space for how the Special Relationship plays out. Syria has been called an arena for strategic competition (Martini, York, \& Young, 2013). How the UK and US compete for influence within the network of other agents help reveal how the Special Relationship is patterned. In addition, Syria functions as a source of conflict between the UK and US in relation to the 29 August 2013 no vote in the British parliament to engage in military action against Syrian government forces. This event produced a slew of headlines that indicated a more than possible existential rupture in the alliance (see, for example, Cohen, 2013; Swaine, 2016; White, 2016). Finally, conflict is a useful lens with which to observe special relationships. The Second World War, the Korean War, the Cold War, the First Gulf War and the 11 September terrorist attacks, amongst many other wide-reaching events, have all honed the relationship and attributed it with a certain range of meanings. As such, the conflict in Syria is a contemporary means to 'test the water' of what the relationship embodies.

\section{Values and Interests: A Bygone Relationship?}

Worth iterating, it is not the claim that both values and interests are meaningless in terms of how the AASR plays out. The argument rather is that bilateral exclusivity, in which values and interests are almost seen as the privileged possessions of the two states, no longer appears to play out and the conflict in Syria reveals a more evolved relationship. Both cultural and functional appeals to we-ness are noticeably sparse. To begin with values, where they do appear, cluster around embedded and long-standing patterns of history and fraternalism based on trust. References to "friend", "partner", "kindred", and "mutual trust" are patent. History, particularly military narratives, is invoked to forge a brotherly bond with a past characterized as a series of conflicts that sealed the AASR and consequently 
produced a mutually enforcing level of faith. The Conservative member Michael Fabricant, in a 2013 parliamentary debate on UK-US bilateral relations, summed up this sentiment:

British and American troops have fought side by side in almost every theatre for the past century, for the same cause and in the same spirit. British territory welcomes American servicemen as though they are our own-not as foreign soldiers, but as kindred spirits. (Fabricant, 2013, October 8)

Historical military engagements have effectively forged a sense of path dependence. This entrenched cooperation is also iterated by the American Deputy Secretary of Defense:

Trust that we will be there for each other, and confidence in each other's stated goals. We have seen it demonstrated again and again, in World War II, in Korea, in Iraq, in Afghanistan, where the British military was with us from the very beginning. (Work, 2015, September 10)

To summarize, the following Table 1 highlights the articulation of common values based on fraternal and historical association:

Table 1. Articlating values: a cultural relationship.

\begin{tabular}{|c|c|}
\hline Britain on America & America on Britain \\
\hline Fraternal: & Fraternal: \\
\hline [W]e possess a bond with the United States of & [W]e are inextricably linked in our values [1] \\
\hline America that I believe must never break [4] & {$[\mathrm{T}]$ he United States will not forget that the } \\
\hline [S] ome of our closest friends in the world-the & United Kingdom stood with us [4] \\
\hline French and the American [28] & [A]s an ally and friend of Israel, together with \\
\hline [W] e want to join our US allies ... we should & Great Britain and others [7] \\
\hline support America unless there is good reason not & [S]hared mutual trust and confidence that exists \\
\hline to $[33]$ & between the U.S. and U.K. military [20] \\
\hline [A]merica's oldest friend, partner and ally [36] & [O]ur friend and ally Great Britain [26] [39] \\
\hline [I]s it not absolutely essential that we back the & [A]n alliance of values, values of freedom, of \\
\hline American efforts in Syria? [58] & maintaining international peace and security, of \\
\hline [T] he special relationship is economically, & making sure that we live in a rules-based world \\
\hline socially and historically beyond single events [71] & {$[39]$} \\
\hline$[\mathrm{K}]$ indred spirits $[71]$ & [T] he British and other allies [41] [44] \\
\hline Historical: & [T] he essential relationship we have with the \\
\hline [W] ho for a century have stood by us and saved & United Kingdom [46] \\
\hline this country. We feel that we have to support & [O]ur British friends [47] \\
\hline \multirow[t]{8}{*}{ them $[80]$} & Historical: \\
\hline & [W]e have a long tradition of great cooperation, \\
\hline & and frankly, that tradition was reinforced today \\
\hline & and it continues [21] \\
\hline & $\mathrm{T}$ ] he special relationship ... is really never more \\
\hline & prominent than it is right now at this period \\
\hline & where we are cooperating on so many different \\
\hline & challenges all at the same time [22] \\
\hline
\end{tabular}


In terms of functionalism, an exclusivist view of the AASR certainly exists but only in a limited sense. The relationship is articulated as both harmonized and allied. Harmonization occurs with policies that are closely aligned particularly with regard to intelligence sharing. Both states operate within a strict web of interdependency whereby foreign policies are conducted in very similar fashion. In addition, both states repeatedly articulate the other as an ally. The White House Press Secretary remarked how Britain is addressed separately from all "other allies and partners" and with regard to the 2013 Ghouta chemical attack: "[a]nd we share the views of the British government about the appalling nature of the transgression that occurred in Syria and are consulting with the British and other allies and partners about the appropriate response" (Carney, 2013, August 27).

Similarly, British Prime Minister David Cameron stated in the House of Commons in 2013: "People talk about escalation; to me, the biggest danger of escalation is if the world community-not just Britain, but America and others-stands back and does nothing. I think Assad will draw very clear conclusions from that." (Cameron, 2013, August 29) On the basis of the limited references to functionalism, the following Table 2 recapitulates the functional references to the AASR categorized around harmonized and allied configurations:

Table 2. Articlating interests: a functional relationship.

\begin{tabular}{|c|c|}
\hline Britain on America & America on Britain \\
\hline Harmonized: & Harmonized: \\
\hline [O] ur alliance with the United States rests on & [O] ur objectives and efforts between the UK and \\
\hline stronger foundations than an expectation of & the U.S. remain closely aligned [39] \\
\hline unquestioning British compliance [17] & Allied: \\
\hline [O] ur alliance is one of the most valuable features & [T] he United States and the United Kingdom are \\
\hline of our foreign policy [18] & continuing to stand together [4] \\
\hline (On the intelligence service): They prize their & [T] he United Kingdom and the United States are \\
\hline relationship with the Americans above all other & leading a historic coalition to deliver ISIL a \\
\hline relationships [19] & lasting defeat [4] \\
\hline [The US and the UK] share an interest [57] & [O]ur allies France, Germany, and the United \\
\hline [V]ery good information sharing between Britain & Kingdom, Australia and Italy [10] \\
\hline and America [51] & [O]ur close/closest allies [12] [38] [39] \\
\hline Allied: & [K]ey allies [19] [39] \\
\hline$[\mathrm{O}]$ nce this House of Commons took its decision, & {$[\mathrm{T}]$ he close counterterrorism partnership that we } \\
\hline I believe it did have an impact on American & have with the United Kingdom [23] \\
\hline politics $[10]$ & {$[\mathrm{T}]$ his coalition $[25]$} \\
\hline [O]ur allies in America and France, and all & The number of areas of cooperation between our \\
\hline like-minded nations [16] & countries has probably never been so broad and \\
\hline [O]ur American allies [35] [48] & numerous [46] \\
\hline \multicolumn{2}{|l|}{ [O]ur closest ally $[40]$} \\
\hline \multicolumn{2}{|l|}{ The United States will do much less if it has to do } \\
\hline so much alone. Moreover, it will do more of what & \\
\hline wants and less of what we might want [50] & \\
\hline
\end{tabular}




\section{Continued}

[O]ur relationship with the US helps to secure,

facilitate and support that US engagement with

the rest of the world [73]

People talk about escalation; to me, the biggest

danger of escalation is if the world

community-not just Britain, but America and

others-standsback and does nothing [87]

[T] he American President would like to have

allies alongside the United States with the

capability and partnership that Britain and

America have [87]

America's Atlanticist commitment is visibly

diminishing [95]

\section{A Normative Relationship}

Normativism, as already mentioned, centers on the prevalence of norms. We argue that these norms are concentrated around three predominant discourses. The first of these is humanitarianism. Instead of a realist-based focus on state security, Anglo-Americanism is defined through the defense of human security in which both countries function as leading contributors to ameliorating the humanitarian cost of the conflict. The United States and the United Kingdom function as the world's largest and second largest donors of humanitarian aid respectively. As stated by the UK Foreign Secretary in London in the summer of 2016:

The current situation on the ground in Syria is dire-heavy bombing by regime forces in and around Aleppo, and there's an escalation of fighting in Daraya. In Aleppo, there's also 300,000 men, women, and children besieged and the sole surviving access route for humanitarian aid has been cut off. The whole country is facing another terrible humanitarian catastrophe, and therefore a potential leap in the number of refugees seeking to escape Syria. (Johnson, 2016, July 19)

Both countries see the other as leaders of a humanitarian network; the AASR has a norm-creating objective drawing states into a multinational grid of actors whose alliance-building is essential to preserving human values and duties. As US Secretary of State remarked in 2013:

... our objectives and efforts between the UK and the U.S. remain closely aligned in four areas in particular. first, working to create the conditions for a Geneva 2 peace process that can lead to a transitional government in Syria; secondly, addressing the desperate humanitarian situation; third, supporting the moderate Syrian opposition and saving lives on the ground; and fourth, mustering a strong international response to the use of chemical weapons. (Kerry, 2013, September 9)

As such, traditional references to the political values of the UK-US characte- 
ristically focusing on democracy, rule of law and freedoms-articulations more characteristic of the nascent AASR during the early Cold War-have given way to more specific human values defended by humanitarian aid, assistance and refugee support.

The second discourse is multilateralism. Humanitarian objectives cannot be achieved solely through any bilateral Special Relationship. Both US and UK agency is lodged within a web of dominant actors. ${ }^{4}$ The multilateralist need is broadly shared by both UK and US spokespeople. From the US perspective, the involvement of other nations contributes to a sense of legitimacy. Great pains are made to include the UK as an important exponent and galvanizer of a proactive Syrian policy. For example, in a speech at the University of Oxford, the US Secretary of Defense announced:

We mobilized the coalition to step up the contributions-not only of the United States and the United Kingdom but of all its members-and get them to join the fight. And we made it clear that there can be no free riders in this campaign. When the war is over and the coalition prevails-which I am certain it will-the United States will not forget that the United Kingdom stood with us. And collectively we will remember who failed to show up for the fight. (Carter, 2016, September 7)

From the US perspective, the multilateralist component of the AASR is very much the instrument to determine ally from non-ally, invoking a "with or us against us" nexus. The international scope of involvement is considered essential with the AASR one of several special relationships producing a planetary pull which induces other states to contribute to the conflict's resolution. In addition, the sheer scope of other countries regarded as important contributors adulterates the argument that involvement in Syria is a unilateralist, neo-imperialist venture. The cultivation of a broad coalition, of which the AASR is a part, globalizes the conflict and affords a level of legitimacy attached to American involvement. Similarly, the constant articulation of "allies", "partners" and "friends" bolsters this internationalism. The UK perspective on multilateralism is similar but slightly different. The AASR is certainly seen as functioning as a galvanizer for a broader coalition. However, references highlight the practice of persuasion; that the United States needs other actors such as Britain not merely to legitimize involvement in Syria but also produce positive strategic outcomes. In a House of Lords debate, one figure argued:

With our experience, our skill and our collective memory, we need to explain more clearly that what is needed in this turmoil of the Middle East is not military intervention or an assertion of American military leadership ... but an America that is a partner with the rising powers of the region. (Lord Howell, 2014, June 25)

${ }^{4}$ The dominance of this discourse is due to the extensive number of actors. Regional powers mentioned include Gulf allies and Arab partners. Individual powers mentioned include Russia, France, Saudi Arabia, Iran and Turkey as well as references to Jordan, Japan, Canada, Australia, Italy, Qatar, the UAE and Finland amongst others. 
From the British standpoint, therefore, multilateralism is a tool to shape American foreign policy by imbuing the notion that the United States is an important, indeed essential actor but only in so far as it operates within a web of other such actors. Several observations, for example, highlight that "this is an international collation, with between 40 and 50 countries involved" (Fallon, 2015, February 23) and "it is more like eight to one or even 10 to one against the notion of unilateral intervention-by 'unilateral', I refer of course to America and France as well." (Lord Phillips, 2013, August 29)

The final component of normativism is the discourse on institutionalism. The role of institutions, however, is noticeably different. The UK perception privileges the role of institutions. The United Nations, the North Atlantic Treaty Organization and the European Union are all articulated as important mechanisms for peaceful resolution. Institutions operate as important conduits for collective security and the AASR, from the British perspective, is a part of this. Indeed, it is special relationships that forge institutional interdependence. The American view is radically different. Institutions do not have their own dynamic independently of the member states that comprise them. States are still very much the highest form of authority within the international system. The paucity of mention of institutions from the US perspective highlights their epiphenomenal role.

To summarize, the AASR possesses a normative nature but with qualifications in the manner by which both states interpret the concept. Humanitarianism is resolute. Both states articulate the essentialness of human security and the need for the amelioration of the human costs of the conflict. In relation to multilateralism, the panoply of other states mentioned, the necessity for multinational negotiation over mere bomb-dropping and the urgency of international relief responses are all suggestive of a world and a consequent contemporary crisis that cannot be so simply resolved by a current and a long since former superpower. Finally, the UK prioritizes the role that international institutions can play but the United States configures institutions as subordinate to their member states. Institutions, from the US viewpoint, simply do not possess their own agency and logic independently of the powerful states that shape them. The following Table 3 underscores the normative nature of the AASR with reference to humanitarianism, multilateralism and institutionalism:

Table 3. Articlating global responsibility: a normative relationship.

\begin{tabular}{ll}
\hline \multicolumn{1}{c}{ Britain on America } & \multicolumn{1}{c}{ America on Britain } \\
\hline $\begin{array}{l}\text { Humanitarian: } \\
\text { Giving more in aid ... than any other country }\end{array}$ & $\begin{array}{l}\text { Humanitarian: } \\
{[\mathrm{H}] \text { as provided some of the strongest }} \\
\text { humanitarian support [26] }\end{array}$ \\
$\begin{array}{l}\text { It's Britain and America behind the biggest } \\
\text { effort to help the victims of Syria [1] }\end{array}$ & {$[\mathrm{I}] \mathrm{s}$ sending troops and humanitarian experts [28] } \\
We are the second biggest bilateral donor of & and have agreed to join us in providing \\
humanitarian aid for Syrian refugees [8] & humanitarian assistance [34] \\
[T]he second largest bilateral humanitarian & [A]re contributing in a number of important \\
donor to this crisis [11] & ways, including ... humanitarian airdrops [39] \\
[T] he largest bilateral contributor [12] & And our special relationship with the UK is not \\
\hline
\end{tabular}




\section{Continued}

[H] ave done more than any other Government apart from that of the United States of America [20] [24]

[S] econd only to America [23]

[W] have done more than any country, save the United States [21] [27]

By far the largest commitment of any European country, and second only to the United States of America [25] [34] [36]

We are the second largest bilateral donor in the world, after America [27]

[T] he highest amount of any European country and second only to the United States of America [32]

$[\mathrm{M}]$ ore than any other country in the world save the United States of America [44]

We are the second biggest bilateral donor to the region and to those refugees [46]

[T] he second largest donor to UNRWA after the United States of America, but it is not nearly enough [47]

Other donors, including the United States of

America and Denmark, are also contributing on a similar scale [67]

[T] he second-largest contributor/donor [68] [69] We are the second largest donor in the world and the largest donor in the European Union [70]

We are the second largest bilateral national donor [76]

\section{Multilateralist:}

[O] ur diplomatic reach [13]

We have a leadership role, and we have a voice that is different from that of the Americans [17]

[A] global coalition of 65 countries and international organisations [24]

[C]o-operation among the Jordanian

Government, the French and the Americans, and the Free Syrian Army [26]

[T]he key players-America, Saudi Arabia and Iran [29]

We are now seeing Iran and Saudi Arabia sitting down around the same table as America and Russia, as well as France, Turkey and Britain [34] [O]f bringing the Americans closer to the Russians, and the Saudis and Turks closer to the Iranians [37]

Our allies include not just the United States of America and France but Gulf states and others [38]

[B] ringing together an international coalition .. Iran, Saudi Arabia, Russia, America, Britain, France, Turkey and others [39]

This is an international coalition, and 50 countries involved [52]

[T] he product of the alliance that the United States ... have been putting together [55] just about Syria, it's not just about a response to this humanitarian crisis [39]

[W] e're in full agreement with our British friends that the humanitarian situation is obviously dire and growing worse [39]

[W]e stand with our friends here in Great Britain, who are the second-largest donor [39] [B] ritain is today pledging an additional $£ 2$ million in food and medical care [47]

Multilateralist:

Saudi Arabia is part of those talks [in Geneva on Syria] together with the Turks, the Qataris, the

United States, Saudi Arabia, France, and Britain [3]

We mobilized the coalition to step up the contributions - not only of the United States and the United Kingdom but of all its members - and get them to join the fight.And we made it clear that there can be no free riders in this campaign [4] [T] he United States and the UK and 18 other nations, including Saudi Arabia, Iran, and every majorcountry with a direct interest and stake in Syria,have all come together to form the

InternationalSyria Support Group [7]

ran, Russia, Saudi Arabia, Emirates-all of the parties that are at the table, key in the regionTurkey, Qatar, others, Egypt, the United States, Britain, Germany, France [9] [F]rance, Germany, and the United Kingdomhave ramped up their contributions [12] [W] e welcome the United Kingdom's decision, Alongwith the announcement by Germany, to commitmore troops and resources to this fight [13] I look forward to working closely with the UK, Germany, and all our Coalition partners on our ongoing shared efforts to degrade and destroy ISIL [15]

[O] ur key allies-including the British, the French, and the Turks [18] A whole bunch of countries ... the United States, ] Saudi Arabia, the Emirates, Turkey, Qatar, Jordan, Egypt, Great Britain, Germany, France, Italy, most of Europe, dozens of countries if not hundreds [19]

[S] everal hundred [people to fight ISIL) from France, from Germany, from Britain [28] [C]lose coordination with the British, the French, the Germans and others [29]

[I] am delighted to join the United Kingdom, France, Germany, Turkey, and Saudi Arabia in 0 bringing together so many friends [31]

[K] ey allies, such as Australia, Canada, France and the United Kingdom are already contributing military support [32] 


\section{Continued}

[N]ot simply following America's coat tails [56] Many of our allies and partners, particularly A regional alliance must include some people with whom we have been enemies [61]

$[\mathrm{P}]$ resident Obama has said, defeating ISIL Denmark, Norway, Finland, Italy, and the United Kingdom [35]

cannot be achieved by military means alone [63] [88]

[A]ll of your Gulf states, Turkey, and then European states-Germany, Italy, France,

With our experience, our skill and our collective memory, we need to explain more clearly that what is needed in this turmoil of the Middle East is not military intervention or an assertion of American military leadership ... but an America that is a partner with the rising powers of the region [64]

[I]t is not for us or for the Americans to determine what sort of regime they have if there is a change in Syria [66]

[I]t is more like eight to one or even 10 to one against the notion of unilateral interventionby "unilateral", I refer of course to America and France as well [81]

The French, the Americans and our Gulf allies [93]

\section{Institutionalist}

[T] the UN can yet bring about a process that leads to an end to the violence [2] Britain, and the United States together [36]

[T] he UK, France, others in the region-will engage [37]

[K] ey allies, such as Australia, Canada, France and the United Kingdom are already contributing military support [39] That [resolution in Syria]'s not just true for Great Britain. That's not just true for countries like Jordan and Turkey that border Syria, but that's also true for Russia [42]

$[\mathrm{T}]$ he French and the British were key partners in thateffort (helping the US in Syria), as were othernations [43]

And we are working with the French and the British and other allies and partners to gather more evidence (for the use of chemical weapons in Syria) [44]

And we continue to work with the French and the British and others, and the Syrian opposition to do That (get information about the use of

[W] now have the opportunity to work with the UN, the Russians, the Americans, the French and others [3]

chemical weapons in Syria) [45]

Institutionalist.

We belong to NATO ... the European Union ... the Commonwealth [4]

[O] ur membership of NATO ... with America and our centrality in the European firmament [13]

[T] he United States counts on strong U.K. leadershipin NATO, the G7, the UN Security Council, the counter-Daesh coalition [6] Even as European countries make important contributions against ISIL, Europe, including NATO, can still do more [8]

[O]ur allies in NATO, Europe, America, and the United Nations [14]

[O] ur partners in NATO, our friends in America and many countries around the world [41]

(The UK): [U]sing its influence in the United Nations to pursue peace through diplomacy rather than gearing up for airstrikes? [45] [W] have to involve the United Nations, the USAand even Arab nations [49]

[R]eplacing Theodore Rooseveltian imperialism with modern international self-restraint and a devotion to the genuine wishes of the whole UN [65]

[W]e have done the US a favour over Syria [72]

[I] organised a special meeting with the UN

Secretary General, the EU, Japan, Turkey,

Canada, France, Australia, Italy, Saudi Arabia 


\section{Continued}

and America [77]

[T] o follow a series of incremental steps, including at the United Nations, to build public confidence and ensure the maximum possible legitimacy for any action [86]

We in this country will use our tailored pressures

with the EU, our American allies and our Arab

and African allies to try to temper these great

forces that are sweeping the Arab world [96]

\section{A Strategic Relationship}

Both the US and UK define themselves and each other as having a distinct military presence and identity. Strategic culture is certainly prevalent within the debates and this has important consequences for how the AASR is configured. However, there are a number of key discourses which produce variance. From the UK perspective, the US is seen as protective, hawkish, destabilizing, unilateralist, and isolationist or ineffective. The US perceives Britain as hawkish and authoritative. As such, there is much more contestation and disagreement about how Britain constructs the US than the other way around. Firstly, Britain views America as possessing a highly protective role. As the foremost military hyper-power, the US offers a defensive security umbrella which creates obligations for Britain and other member states. As one Conservative Party figure warned,

We all know that for too long we have ridden on the coat tails of America. Since the 1990s and the end of the cold war, I am afraid that we have witnessed a radical downturn in the US military commitment on the European continent. (Leigh, 2015, October 23)

The AASR is part of a broader security network under threat from an expectant Europe too complacent in its belief that America will be every ready to defend the continent.

The second discourse focuses on hawkishness-a stance which advocates a belligerent response. The US position unambiguously privileges armed action. It places a heavy role on the UK as being an instrumental provider and contributor in this area. As Secretary Kerry announced in 2015:

So just yesterday, our campaign to degrade and destroy Daesh grew stronger when the United Kingdom voted to join coalition partners in striking targets in Syria. And we welcome the United Kingdom's decision, along with the announcement by Germany, to commit more troops and resources to this fight. Both of those steps are clear signs of the international community's unity and resolve. (Kerry, 2015, December 3)

Three aspects underscore the US focus on a hawkish Britain. The first is agential. A pyramidal hierarchy exists: US as hegemon, Britain as major power with other actors as medium powers. Second, military power is a given. The hard power of hawkishness is a reality states need to muster to deal with the Hobbesian "state of nature" into which Syria has either descended or been dragged. 
Third, security is the most dominant value. Specifically, America effectively props up a security framework, influenced by Britain and other powers, which extends to and shapes how states engage. Although the US configures Britain's hawkish role favorably, and subsequently engenders the AASR with a notable military presence, the UK is far more reticent about any positive impacts involved with an armed response. As Jeremy Corbyn, before becoming Labour leader stated in 2013:

During their meetings with President Obama and Secretary Kerry, did the Prime Minister or Foreign Secretary have an opportunity to say to Secretary Kerry, "Stop spending all your energies flying desperately around Europe and North Africa looking for allies in a war that nobody wants. Instead, put them into bringing about a diplomatic peaceful solution that must include Iran, Russia and all the neighboring countries, most of whom do not support a war anyway"? (Corbyn, 2013, September 9)

Unilateralism must be renounced to make way for synergies of alliance building and cooperation. In addition, such responses are further predicated on the folly of military action and instead are routed through an appeal to non-military approaches focusing on a diplomatic and mediated resolution.

The third manner in which the US is configured is as a destabilizer. Here history plays an important role as Western involvement in the Middle East is vilified. As the Conservative minister Kenneth Clarke warned:

We should have learnt in the last 15 years-when on the whole, American and western policy in the entire middle east has been a catastrophe-that leaping into military activity without a well-judged policy, a well-judged diplomacy and a well-judged strategy has contributed to the extraordinary state of anarchy that has now broken out across the region. (Clarke, 2014, September 10)

The military campaigns in Afghanistan, Iraq and Libya loom large and perpetuate the argument that any foreign meddling in the Middle East, at least formulated under a 'boots on the ground' policy, will stoke sectarian tensions and produce even more volatility and security threats.

A fourth discourse draws attention to unilateralist fears. Again, recent Middle East conflicts along with the spike in international terrorism in general have produced a war-weariness and all seem like decisive factors in rendering a Britain at odds with its historical Atlanticism. The unilateralism attached to an American-dominated policy also raises issues concerning sovereignty. As one Labour Party minister asked, "why a sovereign independent state called Great Britain should automatically fall in line in support of military action." (McDonnell, 2013, August 29) Capacity alone, at least as it is lodged within military capability, will not achieve desired outcomes and a unilateralist American reaction will merely repeat the experiences of Iraq and Afghanistan.

The last British discourse on America conversely highlights an isolationist/ineffective role; that is, the lack of leadership of the US has rendered the international community redundant and has enabled the conflict to fester. References focus on the "absent" (Mitchell, 2016, December 13), "ineffective" (Lord 
Low, 2015, December 2) and "timid approach of America” (Wilson, 2016, October 11), with an American President labelled as "nervous, hesitant and cautious" (Lord Ashdown, 2013, August 29) and "hugely reluctant to be involved" (Rifkind, 2013, July 11). The AASR here is notably about guidance and direction. A rudderless America, with an ambivalent President, has effectively lost its way. As such, for some British commentators, the US doing too little is a response to the fear of it doing too much.

Finally, the US configures Britain as authoritative. Britain possesses a sense of agency and influence that does pattern international relations. This occurs against the backdrop of the British parliamentary no vote to engage in military action in Syria on 29 August 2013. As remarked by John Kerry:

The position of the United Kingdom, following our parliamentary vote 10 days ago is well known, and the government-as you know, in the government, we fully respect the decision made by the House of Commons. But our objectives and efforts between the UK and the U.S. remain closely aligned. (Kerry, 2013, 9 September)

Britain seems to exert a pressure on the American legislature and its authority is used as a means to bolster the legitimacy of any military engagement in Syria. As such, despite this rift, the AASR seems energetic and a proactive UK is certainly underscored within the American perception.

To sum up, the strategic cultural configuration of the AASR has a number of important dimensions. Britain is certainly not at odds with military action and lauds the protective and essential nature of America's role. International peace and security are political values under siege and the principle actors, regional and global powers, are responsible for their defense. However, the AASR is marred by differing security ideologies. For Britain, unilateralist military action will have destabilizing effects on the region. The state-centric capacity for violence must be subordinate to a broader coalition with institutions and other actors taking a dominant role. For the United States, militarism is an inevitable response to dealing with the mayhem in Syria. Ironically, an American preoccupation with armed responses renders its policy hesitant and fruitless. The following table synopsizes the strategic cultural dimension to the AASR (Table 4).

Table 4. Articlating power: a strategic relationship.

\begin{tabular}{|c|c|}
\hline Britain on America & America on Britain \\
\hline Protective: & Authoritative: \\
\hline [O]ur defence will always be anchored in our & {$[\mathrm{I}] \mathrm{n}$ the wake of a failed vote in England, it } \\
\hline unbreakable alliance with the United States of & became even more imperative that the President \\
\hline America and in the primacy of NATO [5] & asked the Congress for the authority [2] \\
\hline [F] or too long we have ridden on the coat tails of & [T] he influence and capabilities of the British \\
\hline America $[42]$ & military and the British government [21] \\
\hline [A]n American trend away from valuing the & {$[\mathrm{T}]$ heir strong support for the plan that the } \\
\hline European continent as a place where defence & President has put forward for dealing with the \\
\hline attention is required $[43]$ & threat that's posed by ISIL [37] \\
\hline [W]e are failing America and Europe over the & [W]e fully respect the decision made by the \\
\hline NATO $2 \%[50]$ & House of Commons [39] \\
\hline
\end{tabular}




\section{Continued}

Hawkish: $\quad$ [T]aking a highly active role in addressing the

[P] ressure from the United States played a major Syria crisis [39]

role in the Government's rush to intervene [17] [T]hey (The Congress members) were impacted For 15 months the Americans have been bombing by what we saw happen in the United Kingdom these positions almost daily, yet the situation on this week when the Parliament of our closest ally the ground in Syria has not changed by one inch failed to pass a resolution with a similar goal, [31] even as the Prime Minister supported taking

[W] see that the odds look as though we will not action [39] succeed, because everything else has gone wrong [W]e certainly do appreciate the strong words [53]

This Government is not America's poodle [57]

[T] he drumbeat of war [62]

[D]iplomacy rather than war [74]

"Stop spending all your energies flying desperately around Europe and north Africa looking for allies in a war that nobody wants" [75]

(On Bombing Syria): That may be how it works in America, but it does not work like that here [90]

\section{Destabilising.}

The last people who should be returning to the scene that have come from senior leaders in the British government [40]

We certainly welcome the role the United

Kingdom has to play (countering the usage of chemical weapons) [40]

[T] he strong words that have come from senior leaders in the British government about what's taken place in Syria [40]

\section{Hawkish:}

[T]he contributions and sacrifices of our local partners there in the region, and of British, American, and coalition servicemembers, we've accelerated the military campaign, we have the momentum firmly on our side [4]

of their former crimes are Britain, France and the The United States, France, the United Kingdom, United States of America [54] Australia, Sweden, Finland, and several others

I think that the idea of the west on its have recently committed ... to contribute even own-America and Britain-taking a war to the middle east is completely wrong [59] more to the military campaign. [5]

[W] e need more nations contributing to the air $[\mathrm{O}] \mathrm{n}$ the whole, American and western policy in campaign [8]

the entire middle east has been a catastrophe [60] [B]ritain has now expanded its air campaign to [A]ny military attack on Syrian territory ... will have disastrous consequences [78]

The United States, and by implication its allies, strike ISIL in Syria [11]

[O]ur campaign to degrade and destroy Daesh high ground in the chemical weapons era [82]

\section{Unilateralist:}

That does not mean, however, that we should allow ourselves to go blindly ... with what the American president of the day wishes to do [18] My biggest fear is that this is all emerging not as a global issue, but as a purely American-led western action [83]

[W] hy a sovereign independent state called Great Britain should automatically fall into line in support of military action [88]

[S] enior American political sources only last weekend talked in terms of retribution as the basis for taking action against Syria [89]

Isolationist/ Ineffective:

He has withdrawn America from the world stage

[6]

[T] he abject failure of the international community [7] grew stronger when the United Kingdom voted

grew stronger when the United Kingdom voted

Syria [13]

$[\mathrm{H}]$ ave ramped up their contributions to our military campaign, which will help us accelerate our effort to destroy ISIL [13]

[T] he right for Great Britain to join us in striking against ISIL in Syria [14]

We look forward to having British forces flying with the Coalition over Syria [15]

join Coalition partners [15]

[S]ince the beginning of the counter-ISIL campaign

the United Kingdom has been one of our most valued partners in fighting ISIL [15]

[A]n even greater British military commitment [16]

[T] he influence and capabilities of the British military and the British government are used [16] 


\section{Continued}

\begin{tabular}{|c|c|}
\hline The Americans have been absent [9] & {$[\mathrm{U}] \mathrm{K}$ has already made a substantial contribution } \\
\hline \multicolumn{2}{|l|}{ [T] he timid approach of America and other allied $t$} \\
\hline forces $[15]$ & [V]ery interested in how they can expand their \\
\hline \multirow{3}{*}{$\begin{array}{l}\text { The actions of the American-led coalition have } \\
\text { been } \\
\text { largely ineffective in degrading ISIL to date [30] }\end{array}$} & efforts to help deal with ISIL inside of Syria [17] \\
\hline & [M]ilitary commitment to our counter-ISIL \\
\hline & campaign [17] \\
\hline \multirow{2}{*}{$\begin{array}{l}\text { We lost a lot of influence with the Americans } \\
\text { because the Prime Minister was foolish enough to }\end{array}$} & The British military has made significant \\
\hline & commitments to that effort [23] \\
\hline say to & [T] heir significant contribution (against ISIL) \\
\hline Barack Obama that we would get involved in & {$[24]$} \\
\hline Syrian operations [48] & [T] he Royal Air Force is now conducting \\
\hline You need only to look at what this American & airstrikes on ISIL positions [26] \\
\hline \multirow{2}{*}{$\begin{array}{l}\text { President has done to see how nervous, hesitant } \\
\text { and cautious he is about taking action [79] }\end{array}$} & [I]n the fight against ISIL, the British people have \\
\hline & already borne a very heavy burden [26] \\
\hline \multirow{3}{*}{$\begin{array}{l}\text { [E]ven together with America and France, we do } \\
\text { not have the will or the power to sustain the } \\
\text { global public good we created [84] }\end{array}$} & [T] he commitment the United Kingdom has \\
\hline & made to the international coalition that will \\
\hline & degrade and defeat ISIL over the next months, in \\
\hline \multirow{2}{*}{$\begin{array}{l}\text { [T] he US does not know what it is trying to do } \\
{[85]}\end{array}$} & the period \\
\hline & [M]ilitary force against ISIL in Iraq [27] \\
\hline \multirow{2}{*}{$\begin{array}{l}\text { Any American activity now will not resolve the } \\
\text { situation [91] }\end{array}$} & [T] heir strong support for the plan that the \\
\hline & President has put forward for dealing with the \\
\hline \multirow{3}{*}{$\begin{array}{l}\text { President Obama, who has been hugely reluctant } \\
\text { to be involved, in any way, militarily in Syria, has } \\
\text { nevertheless been persuaded [ } 92]\end{array}$} & threat that's posed by ISIL [30] \\
\hline & [A]re contributing in a number of important \\
\hline & ways, including by providing military assistance \\
\hline \multicolumn{2}{|c|}{ Why have they failed to act on President Obama's and humanitarian airdrops [33] } \\
\hline \multirow[t]{3}{*}{ so-called red line? [94] } & {$[\mathrm{W}] \mathrm{e}$ are pleased to see the strong support from } \\
\hline & diament for members of the \\
\hline & British military [40] \\
\hline
\end{tabular}

\section{Conclusion: Transcending Specialty}

It has been observed before that a Hobbesian-Kantian schism divides the US and Europe (see, for example, Kagan, 2003): America as the Hobbesian state par excellence, a colossus traversing an anarchical world; Europe as Kantian, ostensibly small states burying their fratricidal pasts in a peaceable and utopian present. From the UK perspective, as a Lockean bridge straddling both worlds, perhaps the AASR-embracing both normative and strategic structures-is logical. It may also be indicative of Britain's nested identities historically functioning as a European, Transatlantic and global actor. In the past, the AASR was a means to Americanize Europe, to ensure a security presence in Europe; as a way to Anglicize America, it was a foreign policy manoeuvre which gave Britain principle whispering access to the superpower's ear. From the findings of the article, it seems that both states have somewhat grown out of the original usage of the Special Relationship. Now it is not as easily defined as an exclusively bilateral bond defined through values and interests.

In terms of the historical narratives concerning the AASR, a particular reading of values and interests has been dominant. Values have been articulated through common language, culture, values, and so forth. Interests have found themselves in the AASR functioning as a tool of foreign policy. The argument concentrates 
on how Britain has long searched for surrogates for loss of empire including the Commonwealth (White, 2014; Haseler, 2012) and the European Economic Community (Enoch Powell, 1975, April 9) most notably. What is apparent from this study, however, is that Britain is rather more lukewarm about its relationship with America than the other way around. Each state does bathe the other in unequivocally positive hews but there are important ruptures. From the American point of view, there is a great deal more caution in casting Britain in a negative light. The US opinion of Britain has far more homogeneity, consistency and unambiguous friendliness than the British perception of the US. The alliance, once so integral to the British sense of Self on the world stage, seems decidedly less so.

Both normative and strategic cultures reinforce one another. Hard power is necessary to try to shape and order the Syrian conflict and the broader international system. In turn, military ambition becomes legitimized so as long as it takes place under the normative structures of humanitarianism, multilateralism and institutionalism. To reiterate, this study has argued that the AASR within the context of the Syrian conflict is configured in three notable ways. These contributions are worth restating. The first is a complement. There is complete agreement that an essential component of the AASR is a humanitarian concentration. Human security, rather than state security, takes precedence. As major donors, each state articulates the other as possessive of a dominant role in this civilian-oriented concern coupled not merely to financial assistance but to the deployment of humanitarian experts, food, medical care and assistance. The many references to the US and the UK as the world's largest donors give a level of qualitative power to this discourse and there is subsequently little ambiguity concerning this observation.

The second impact on the AASR is a process of mild differentiation. This issue concerns the role of multilateralism. Broad agreement on the need for a multilateralist approach is evident. Both states articulate the other as operating within a panoply of important actors. From the British point of view, the USA is simply an authority that matters. An American-less world is utterly inconceivable. Britain is simply tied to the US in an inescapable logic of co-dependency that is a normalized and naturalized reality. From the American perspective, there is a definite admission of Britain as being authoritative and listened to which highlights a pivotal power status (Marsh \& Baylis, 2006). British involvement from an American perspective might also resonate with "buck-passing" (Mearsheimer, 2001: pp. 156-157) with the objective of coaxing other states' to shoulder a conflict's burden. However, in contradiction to such a realist premise, the forging of multilateralism is a norm based component; that the conflict, once seen as a civil war, has actually become globalized, and the need for many actor involvement is both a recognition of this as well as an admission that collective security mechanisms involve many states not merely a few. Global problems require global reactions and the AASR, along with many crisscrossing partnerships and affiliations, is an attempt to galvanize collective action. Where differing in- 
terpretations of the AASR do occur here is with regard to institutions. The UK, as mentioned, places intergovernmental institutions at the forefront of the process. The collectivization of security is the best means to deal with security and humanitarian crises. From the US perspective, authority is very much in the hands of key states rather than institutions and it is the role of these principle actors that need to be energized.

The final issue is a notable clash between US-UK readings of the Special Relationship. Both states certainly view one another through a military lens; that the capacity to engage with an armed response is very much characteristic of each state's identity. The early history of the AASR, built off the back of terrible conflict, seems to resonate in the present day. However, and perhaps cast in the long shadow of recent military involvement in the Middle East, conflict becomes the symbolic test of how independent a state is. With specific reference to the British position, whatever transatlantic relationship exists, it must not be allowed to influence or adulterate the sanctity of national autonomy. As such, tensions are articulated in three ways; the first is a suspicion of the American proclivity to over-rely on military muscle alone; the second is a more specific criticism of an American administration that is muddled and weak; and the third is the fear of an America that is cocooning itself and ignoring the global responsibilities and leadership in which it should be engaging. This is a curious mix because America appears to be criticized for doing too much, by being belligerent, and for doing too little, by being excessively passive. Once again, the role of institutions and multilateralism play a key part. The AASR in terms of its military component is seemingly not an end in itself, but a means for achieving one. As such, its military nature must operate within a broader spectrum of other regional and non-regional allies. Unilateral military solutions render political resolution impossible and are subsequently counterproductive. As such, the exercise of hard power is both destabilizing and destructive, and the AASR, in possessing a coalition-building animus, is an antidote to this.

In conclusion, it is worth highlighting two shortcomings which might impact on future studies of the AASR. The first is context-specific. The $18^{\text {th }}$ century British Prime Minister Lord Palmerston is said to be the originator of the well-known aphorism "nations have no permanent friends or allies, they only have permanent interests." Permanency between states certainly appears to be elusive. Special relations may well lack the durability attributed to them. Syria is but one context within which the AASR might be read but excludes the many other frameworks and influences that might configure the AASR in different ways. A synchronic study taking a snapshot in time might simply be less information rich than a more diachronic, evolutionary reading. Secondly and relatedly, special relationships are subject to change. Within the current government of the United States, and the shifting situation in Syria with an ostensibly defeated so-called Islamic State, is there any comparable shift in the AASR? Staying within the timeframe of this study, the first official statements by the then Presi- 
dent-elect Donald Trump on Syria revealed a changing strategy:

I ve had an opposite view of many people regarding Syria ... My attitude was you' re fighting Syria; Syria is fighting ISIS; and you have to get rid of ISIS. Russia is now totally aligned with Syria, and now you have Iran, which is becoming powerful, because of us, is aligned with Syria ... Now we're backing rebels against Syria, and we have no idea who these people are. (Lister, 2016, November 17)

Certainly, the US President's decision in the summer of 2017 to stop the covert program to arm and train Syrian rebels, with one official labelling the decision a victory for President Vladimir Putin (Jaffe \& Entous, 2017, July 19), is coupled to the fact that US priorities no longer consider removing Bashar Al-Assad from power (Nichols, 2017, March 30). Naturally, such a position may well take its energy from what are certainly perceived as the failures of the intervention-lite strategy of the Obama administration (Bandow, 2016, November 18). However, what it points to is an America working with Russia rather than against, which certainly renders the AASR weakened. Indeed, one may even argue that a broader "America First" strategy has little scope for any special relationships at all.

From a British perspective, the AASR might also be fluctuating. The Brexit saga appears to have rendered Syria and broader foreign involvement a less prominent priority with intra-European matters taking precedence over extra-European affairs, particularly costly conflicts. In addition, the British Prime Minister Theresa May has been vocal in her condemnation of Russian support for indiscriminate bombing of civilians in Syria (Asthana, 2016, November 28). Such censure seemed at odds with the current American administration's early overtures to President Putin. Yet, as it stands, Russia currently faces a number of US and EU-led sanctions based on the 2014 annexation of Crimea, the poisoning of Sergei and YuliaSkripalin Salisbury, the UK in March 2018, as well as alleged Russian cyber activity. Syria is at risk of being replaced with newer security threats.

Nonetheless, and despite these potential outcomes, a weakening of the AASR is no indication of its obsolescence; it is merely the latest invocation of its propensity to change. As an alliance, as with all, it adapts and adopts. Indeed, both states seem locked into a web of mutuality; a web so tightly bound as to inevitably render both states as perennial allies even if that permanency takes on new meanings of similarities and differences between them. As such, the discourses reveal that these meanings, clustered around the twin themes of normative and strategic cultures, nonetheless still show that the AASR is active. Such relationships, straddling the middle ground between the excessive zeal of going-it-alone and the listlessness of devil-may-care, may be argued to be vital, particularly when applied to the heavy costs of international conflict.

\section{Conflicts of Interest}

The authors declare no conflicts of interest regarding the publication of this paper. 


\section{References}

Åhäll, L., \& Berg, S. (2013). Predication, Presupposition and Subject-Positioning. In L. J. Shepherd (Ed.), Critical Approaches to Security: An Introduction to Theories and Methods. Oxford: Routledge.

Albright, M. (1998). Interview on 'The Today Show' with Matt Lauer. Columbus, OH: NBC-TV.

Aldrich, R. J. (1998). British Intelligence and the Anglo-American 'Special Relationship' during the Cold War. Review of International Studies, 24, 331-351. https://doi.org/10.1017/S0260210598003313

Allen, H. C. (1985). A Special Relationship? The Royal Institute of International Affairs, $19,408$.

Asthana, A. (2016). Theresa May Calls for International Pressure on Putin over Syria. The Guardian.

Bandow, D. (2016). President-Elect Donald Trump: Stay Out of Syria. Forbes. https://www.forbes.com/sites/dougbandow/2016/11/18/president-elect-donald-trumpstay-out-of-syria/\#178339d570c3

Baylis, J., Smith, S., \& Owens, P. (2014). The Globalization of World Politics (6th ed.) Oxford: Oxford University Press.

BiallyMattern, J. (2004). Ordering International Politics. Identity, Crisis and Representational Force. New York and Oxford: Routledge.

Brown, G. (2008). Speech to the Lord Mayor's Banquet. London, UK. In W. Wallace, \& C. Phillips (2009). Reassessing the Special Relationship. International Affairs, 85, 2.

Bukovansky, M., Clark, I., Eckersley, R., Price, R., Reus-Smit, C., \& Wheeler, N. J. (2012). Special Responsibilities: Global Problems and American Power. Cambridge: Cambridge University Press. https://doi.org/10.1017/CBO9781139108812

Cameron, D. (2013). House of Commons (Vol. 566, col. 1433).

Campbell, C., \& Rockman, V. A. (2001). Third Way Leadership, Old Way Government: Blair, Clinton and the Power to Govern. The British Journal of Politics and International Relations, 3, 36-48. https://doi.org/10.1111/1467-856X.00048

Carney, J. (2013). Press Briefing by Press Secretary Jay Carney. Washington DC: The White House.

https://obamawhitehouse.archives.gov/the-press-office/2013/08/27/press-briefing-press -secretary-jay-carney-8272013

Carter, A. (2016). Remarks on the 'U.S.-UK Alliance and the Future of the Princi pled International Order'. UK: Blavatnik School of Government, University of Oxford.

https://www.defense.gov/News/Speeches/Speech-View/Article/936974/remarks-on-the -us-uk-alliance-and-the-future-of-the-principled-international-or/

Chappell, L. (2009). Differing Member State Approaches to the Development of the EU Battle. Group Concept: Implications for CSDP. European Security, 18, 417-439. https://doi.org/10.1080/09662839.2010.498419

Churchill, W. (1946). The Sinews of Peace. Fulton, MO: Westminster College. https://www.winstonchurchill.org/resources/speeches/1946-1963-elder-statesman/the-s inews-of-peace/

Clarke, K. (2014). House of Commons (Vol. 585, col. 941).

Cohen, R. (2013). A Much Less Special Relationship. The New York Times. 
Coker, C. (1992). Britain and the New World Order: The Special Relationship in the 1990s (Vol. 68, No. 3). The Royal Institute of International Affairs.

Colman, J. (2004). A "Special Relationship"? Harold Wilson, Lyndon B Johnson and Anglo-American Relations "at the Summit", 1964-8. Manchester: Manchester University Press. https://doi.org/10.7765/9781526137203

Corbyn, J. (2013). House of Commons (Vol. 567, col. 697).

Danchev, A. (1996). On Specialness. International Affairs, 72, 737-750.

Dickey, J. S. (1975). Canada and the American Presence: The United States Interest in an Independent Canada. New York: New York University Press.

Dickie, J. (1994). "Special” No More: Anglo-American Relations: Rhetoric and Reality. London: Weidenfeld and Nicholson.

Dobson, A. P., \& Marsh, S. (2013). Introduction. In A. P. A Dobson, \& S. Marsh (Eds.), Anglo-American Relations: Contemporary Perspectives (p. 3). London and New York: Routledge.

Doty, R. (1993). Foreign Policy as Social Construction: A Post-Positivist Analysis of U.S. Counterinsurgency Policy in the Philippines. International Studies Quarterly, 37, 297-320. https://doi.org/10.2307/2600810

Ellis, S. (2004). Britain, America, and the Vietnam War. Westport, CT: Praeger.

Ellis, S. (2009). Historical Dictionary of Anglo-American Relations. Lanham, MD: Scarecrow Press.

Enoch Powell, J. (1975). House of Commons (Vol. 889, cols. 1300-1).

Erskine, T. (2003). Assigning Responsibilities to Institutional Moral Agents: The Case of States and "Quasi-States". In T. Erskine (Ed.), Can Institutions Have Responsibilities? Collective Moral Agency and International Relations (pp. 19-40). Basingstoke: Palgrave Macmillan. https://doi.org/10.1057/9781403938466

Fabricant, M. (2013). House of Commons (Vol. 568, col. 3WH).

Fallon, M. (2015). House of Commons (Vol. 593, col. 12).

Gray, C. S. (1999). Strategic Culture as Context: The First Generation of Theory Strikes Back. Review of International Studies, 25, 1.

Harnisch, S. (2017). Special Relationships in Foreign Policy. Oxford Research Encyclopedia of Politics.

https://www.uni-heidelberg.de/md/politik/harnisch/person/publikationen/harnisch_sp ecial_relationships_in_foreign_policy.pdf

Harnisch, S., Brummer, K., \& Oppermann, K. (2015). Sonderbeziehungenals Nexus zwischen Au Benpolitikund internationalen Beziehungen. Baden-Baden: Nomos.

Haseler, S. (2012). The Grand Delusion: Britain after Sixty Years of Elizabeth II. London and New York: I. B. Taurus \& Co. Ltd.

Hitchens, C. (1990). Blood, Class and Nostalgia: Anglo-American Ironies. London: Vintage.

Human Rights Watch (2018). Syria: Events of 2016. Human Rights Watch. https://www.hrw.org/world-report/2017/country-chapters/syria

Jaffe, G., \& Entous, A. (2017). Trump Ends Covert CIA Program to Arm Anti-Assad Rebels in Syria, a Move Sought by Moscow. Washington Post.

Johnson, B. (2016). Joint Press Availability with U.K. Foreign Secretary Boris Johnson. London: Foreign and Commonwealth Office. 
https://2009-2017.state.gov/secretary/remarks/2016/07/260264.htm

Judt, T. (2005). Postwar: A History of Europe since 1945. London and New York: Penguin Books.

Kaarbo, J., \& Kenealy, D. (2016). No, Prime Minister: Explaining the House of Commons' Vote on Intervention in Syria. European Security, 25, 1. https://doi.org/10.1080/09662839.2015.1067615

Kagan, R. (2003). Of Paradise and Power: America and Europe in the New World Order. New York: Alfred A. Knopf.

Kerry, J. (2013). Remarks with United Kingdom Foreign Secretary Hague. London: United Kingdom Foreign and Commonwealth Office. https://2009-2017.state.gov/secretary/remarks/2013/09/213956.htm

Kerry, J. (2015). Remarks at OSCE Ministerial Meeting. Belgrade: Kombank Arena. https://2009-2017.state.gov/secretary/remarks/2015/12/250319.htm

Kissinger, H. (1982). Reflections on a Partnership: British and American Attitudes to Postwar Foreign Policy. International Affairs, 58, 571-587.

Leigh, E. (2015). House of Commons (Vol. 600, col. 1293).

Lister, C. (2016). Trump's Syria Strategy Would Be a Disaster. Foreign Policy. http://foreignpolicy.com/2016/11/17/trumps-syria-strategy-would-be-a-disaster/

Lord Ashdown (2013). House of Lords (Vol. 747, col. 1734).

Lord Howell of Guildford (2014). House of Lords (Vol. 754, col. 1325).

Lord Low (2015). House of Lords (Vol. 767, col. 1141).

Lord Phillips of Sudbury (2013). House of Lords (Vol. 747, col. 1779).

Manners, I. (2002). Normative Power Europe: A Contradiction in Terms? Journal of Common Market Studies, 40, 235-258. https://doi.org/10.1111/1468-5965.00353

Manners, I. (2009). The Concept of Normative Power in World Politics. Daansk Institut for Internationale Studier.

http://pure.diis.dk/ws/files/68745/B09_maj_Concept_Normative_Power_World_Politi cs.pdf

Marcussen, M., Risse, T., Engelmann-Martin, D., Joachim Knopf, H., \& Roscher, K. (1999). Constructing Europe? The Evolution of French, British and German Nation State Identities. Journal of European Public Policy, 6, 4. https://doi.org/10.1080/135017699343504

Marsh, S. (2005). Foreign Policy. In P. Dorey (Ed.), Developments in British Public Policy (p. 8). London: SAGE.

Marsh, S., \& Baylis, J. (2006). The Anglo-American "Special Relationship": The Lazarus of International Relations. Diplomacy \& Statecraft, 17, 1.

https://doi.org/10.1080/09592290500533841

Martini, J., York, E., \& Young, W. (2013). Syria as an Arena of Strategic Competition. Santa Monica, CA: RAND Corporation.

https://www.rand.org/pubs/research_reports/RR213.html

McDonnell, J. (2013). House of Commons (Vol. 566, col. 1461).

Mearsheimer, J. (2001). The Tragedy of Great Power Politics. New York: W. W. Norton.

Milliken, J. (1999). The Study of Discourse in International Relations: A Critique of Research and Methods. European Journal of International Relations, 5, 225-254.

https://doi.org/10.1177/1354066199005002003 
Mishra, V. (2016). Japan and India: A Special Relationship? The National Interest. http://nationalinterest.org/feature/japan-india-special-relationship-18491

Mitchell, A. (2016). House of Commons (Vol. 618, Standing Order No. 4).

Nichols, M. (2017). U.S. Priority on Syria No Longer Focused on "Getting Assad Out": Hale. Reuters.

https://www.reuters.com/article/us-mideast-crisis-syria-usa-haley/u-s-priority-on-syria -no-longer-focused-on-getting-assad-out-haley-idUSKBN1712QL

Oppermann, K., \& Hansel, M. (2016). The Ontological Security of Special Relationships: The Case of Germany and Israel. In CEEISA-ISA Joint International Conference (pp. 1-30). Ljubljana, Slovenia.

Orwell, G. (1947-8). Defence of Comrade Zilliacus. In S. Orwell, \& I. Angus (Eds.), (2000). In Front of Your Nose, 1945-1950 (Collected Essays, Journalism and Letters of George Orwell). New Hampshire: David R. Godine.

Reynolds, D. (1985-6). A “Special Relationship"? America, Britain and the International Order since the Second World War. International Affairs, 62, 1-20.

Reynolds, D. (1988-9). Rethinking Anglo-American Relations. International Affairs, 65, 89-112. https://doi.org/10.2307/2620984

Rifkind, M. (2013). House of Commons (Vol. 566, Vol. 598).

Rosencrance, R. (1998). The European Union: A New Type of International Actor. In J. Zielonka, (Ed.), Paradoxes of European Foreign Policy (p. 22). The Hague: Kluwer Law International.

Savic, B. (2016). Behind China and Russia's "Special Relationship”. The Diplomat. https://thediplomat.com/2016/12/behind-china-and-russias-special-relationship/

Schmidt, G. (2005). The "Special Relationship": How Much Longer Will It Last? In U. Lehmkuhl, \& G. Schmidt (Eds.), From Enmity to Friendship. Anglo-American Relations in the 20th Century (pp. 101-114). Augsburg: WißnerVerlag.

Sengupta, S. (2016). A Senior Russian Envoy's Take on Relations with the United States: "Pretty Bad". The New York Times.

Skjelsbaek, K. (1979). Militarism, Its Dimensions and Corollaries: An Attempt at Conceptual Clarification. Journal of Peace Research, 16, 213-229. https://doi.org/10.1177/002234337901600303

Strong, J. (2015). Why Parliament Now Decides on War: Tracing the Growth of the Parliamentary Prerogative through Syria, Libya and Iraq. British Journal of Politics and International Relations, 17, 604-622. https://doi.org/10.1111/1467-856X.12055

Swaine, J. (2016). David Cameron's Syria Defeat Could Signal End of the "Special Relationship", Politicians Warn. The Daily Telegraph.

UNHCR (2005). Needs Soar as Number of Syrian Refugees 3 Million. United Nations High Commissioner for Refugee. http://www.unhcr.org

White, M. (2016). Syria: After Years of Distancing, How Special Is the US-UK Relation-Ship? The Guardian.

White, N. (2014). Decolonisation: The British Experience since 1945. London and New York: Routledge. https://doi.org/10.4324/9781315780207

Wilson, S. (2016). House of Commons (Vol. 615, col. 180).

Work, R. (2015). Speech at the Royal United Services Institute. London: White Hall. http://www.defense.gov/News/Speeches/Speech-View/Article/617128/royal-united-serv ices-institute-rusi 
$\mathrm{Xu}$, R. (2016). Institutionalization, Path Dependence and the Persistence of the Anglo-American Special Relationship. International Affairs, 92, 5.

https://doi.org/10.1111/1468-2346.12705 


\section{Appendix 1: Britain on America}

[1] Cameron, D. (2015) Leader's Speech. Manchester, UK. http://www.britishpoliticalspeech.org/speech-archive.htm

[2] Corbyn, J. (2015) Leader's Speech. Brighton, UK. http://www.britishpoliticalspeech.org/speech-archive.htm

[3] Clegg, N. (2015) Leader's Speech. Glasgow, UK. http://www.britishpoliticalspeech.org/speech-archive.htm

[4] Hague, W. (2012) Foreign Secretary's Speech. Birmingham, UK. http://www.britishpoliticalspeech.org/speech-archive.htm

[5] Hague, W. (2011) Foreign Secretary’s Speech. Manchester, UK. http://www.britishpoliticalspeech.org/speech-archive.htm

[6] Lord Blencathra of Penrick (2017, January 19) House of Lords. Vol. 778, col. 402.

[7] Lord Hannay of Chiswick (2017, January 19) House of Lords. Vol. 778, col. 390.

[8] May, T. (2016, December 19) House of Commons. Vol. 618, col. 1191.

[9] Mitchell, A. (2016, December 13) House of Commons. Vol. 618, standing order no. 4.

[10] Osborne, G. (2016, December 13) House of Commons. Vol. 618, standing order no. 4.

[11] Baroness Evans of Bowes Park (2016, October 24) House of Lords. Vol. 776, col. 33.

[12] Baroness Goldie of Bishopton (2016, October 20. House of Lords. Vol. 774, col. 2482.

[13] Mitchell, A. (2016, October 11) House of Commons. Vol. 615, col. 170.

[14] Mitchell, A. (2016, October 11) House of Commons. Vol. 615, col. 172.

[15] Wilson, S. (2016, October 11) House of Commons. Vol. 615, col. 180.

[16] Johnson, B. (2016, October 11) House of Commons. Vol. 615, col. 209.

[17] Thornberry, E. (2016, July 13) House of Commons. Vol. 613, col. 333.

[18] Clarke, K. (2016, July 13) House of Commons. Vol. 613, col. 340.

[19] Clarke, K. (2016, July 13) House of Commons. Vol. 613, col. 341.

[20] Howarth, G. (2016, May 9) House of Commons. Vol. 609, col. 492.

[21] Cameron, D. (2016, March 21) House of Commons. Vol. 607, col. 1245.

[22] Baronness Neville-Rolfe of Chilmark (2016, January 14) House of Lords. Vol. 768, col. 502 .

[23] Cameron, D. (2016, January 5) House of Commons. Vol. 604, col. 26.

[24] Cameron, D. (2016, January 5) House of Commons. Vol. 604, col. 40.

[25] Earl Howe (2015, December 2) House of Lords. Vol. 1095, col. 1194.

[26] Cameron, D. (2015, December 2) House of Commons. Vol. 603, col. 327.

[27] Cameron, D. (2015, December 2) House of Commons. Vol. 603, col. 334.

[28] Cameron, D. (2015, December 2) House of Commons. Vol. 603, col. 337.

[29] Baroness Stowell of Beeston (2015, December 2) House of Lords. Vol. 767, col. 1110.

[30] Lord Low of Dalston (2015, December 2) House of Lords. Vol. 767, col. 1141.

[31] Sheppard, T. (2015, November 30) House of Commons. Vol. 603, col. 86. 
[32] Green, C. (2015, November 30) House of Commons. Vol. 603, col. 108.

[33] Lilley, P. (2015, November 30) House of Commons. Vol. 603, col. 54.

[34] Baroness Stowell of Beeston (2015, November 26) House of Lords. Vol. 767, col. 817.

[35] Lord Wright of Richmond (2015, November 26) House of Lords. Vol. 767, col. 829.

[36] Cameron, D. (November 26, 2015) House of Commons. Vol. 602, col. 1492.

[37] Cameron, D. (November 26, 2015) House of Commons. Vol. 602, col. 1499.

[38] Cameron, D. (November 26, 2015) House of Commons. Vol. 602, col. 1507.

[39] Cameron, D. (November 17, 2015) House of Commons. Vol. 602, col. 536.

[40] Howarth, G. (2015, October 23) House of Commons. Vol. 600, col. 1271.

[41] Bellingham, H. (2015, October 23) House of Commons. Vol. 600, col. 1291.

[42] Leigh, E. (2015, October 23) House of Commons. Vol. 600, col. 1293.

[43] Leigh, E. (2015, October 23) House of Commons. Vol. 600, col. 1294-5.

[44] Baroness Stowell of Beeston (2015, October 19) House of Lords. Vol. 765, col. 497.

[45] O’Hara, B. (2015, October 19) House of Commons. Vol. 600, col. 497.

[46] May, T. (2015, October 12) House of Commons. Vol. 600, col. 19.

[47] Baroness Tonge (2015, September 16) House of Lords. Vol. 764, col. 1923.

[48] Lord Davies of Stamford (2015, September 16) House of Lords. Vol. 764, cols. 1926-7.

[49] Baroness Prashar (2015, September 16) House of Lords. Vol. 764, col. 1931.

[50] Lord Temple-Morris (2015, June 17) House of Lords. Vol. 762, col. 1222.

[51] Cameron, D. (2015, June 10) House of Commons. V. 596, col. 1203.

[52] Fallon, M. (2015, February 23) House of Commons. Vol. 593, col. 12.

[53] Dobson, F. (2014, September 26) House of Commons. Vol. 585, col. 1310.

[54] Galloway, G. (2014, September 26) House of Commons. Vol. 585, col. 1301.

[55] Campbell, M. (2014, September 26) House of Commons. Vol. 585, col. 1284.

[56] Mulholland, G. (2014, September 26) House of Commons. Vol. 585, col. 1349.

[57] Gardiner, B. (2014, September 26) House of Commons. Vol. 585, col. 1353.

[58] Jenkin, B. (2014, September 26) House of Commons. Vol. 585, col. 1279.

[59] Blears, H. (2014, September 26) House of Commons. Vol. 585, col. 1282.

[60] Clarke, K. (2014, September 10) House of Commons. Vol. 585, col. 941.

[61] Clarke, K. (2014, September 10) House of Commons. Vol. 585, col. 943.

[62] Llwyd, E. (2014, September 10) House of Commons. Vol. 585, col. 961.

[63] Miliband, E. (2014, September 1) House of Commons. Vol. 585, col. 28.

[64] Lord Howell of Guildford (2014, June 25) House of Lords. Vol. 754, col. 1325.

[65] Lord Dykes (2014, June 19) House of Lords. Vol. 754, col. 994.

[66] Lord Carlile of Berriew (2014, February 27) House of Lords. Vol. 752, col. 1062.

[67] Hague, W. (2014, February 6) House of Commons. Vol. 575, col. 34WS.

[68] Clarke, T. (2014, January 29) House of Commons. Vol. 574, col. 900.

[69] Lord Taylor of Holbeach (2014, January 20) House of Lords. Vol. 751, col. 540.

[70] Harper, M. (2014, January 20) House of Commons. Vol. 574, col. 31. 
[71] Fabricant, M. (2013, October 8) House of Commons. Vol. 568, col. 4WH.

[72] Lewis, J. (2013, October 8) House of Commons. Vol. 568, col. 9WH.

[73] Spellar, J. (2013, October 8) House of Commons. Vol. 568, col. 16WH.

[74] Redwood, J. (2013, October 8) House of Commons. Vol. 568, col. 33.

[75] Corbyn, J. (2013, September 9) House of Commons. Vol. 567, col. 697.

[76] Cameron, D. (2013, September 9) House of Commons. Vol. 567, col. 693.

[77] David Cameron, H.C. September 9, 2013, vol. 567, col. 685.

[78] Lord Wright of Richmond (2013, August 29) House of Lords. Vol. 747, col. 1729.

[79] Lord Ashdown of Norton-sub-Hamdon (2013, August 29) House of Lords. Vol. 747 , col. 1734

[80] Lord Bilimoria (2013, August 29) House of Lords. Vol. 747, col. 1775.

[81] Lord Phillips of Sudbury (2013, August 29) House of Lords. Vol. 747, col. 1779.

[82] Lord Ramsbotham (2013, August 29) House of Lords. Vol. 747, col. 1781.

[83] Lord Howell of Guildford (2013, August 29) House of Lords. Vol. 747, col. 1782.

[84] Lord Desai (2013, August 29) House of Lords. Vol. 747, col. 1783.

[85] Lord Wigley (2013, August 29) House of Lords. Vol. 747, col. 1789.

[86] Cameron, D. (2013, August 29) House of Commons. Vol. 566, col. 1428.

[87] Cameron, D. (2013, August 29) House of Commons. Vol. 566, col. 1433.

[88] McDonnell, J. (2013, August 29) House of Commons. Vol. 566, col. 1461.

[89] Durkan, M. (2013, August 29) House of Commons. Vol. 566, col. 1463.

[90] Bone, P. (2013, August 29) House of Commons. Vol. 566, col. 1526.

[91] Havard, D. (2013, August 29) House of Commons. Vol. 566, col. 1495.

[92] Rifkind, M. (2013, July 11) House of Commons. Vol. 566, vol. 598.

[93] Cameron, D. (2013, June 19) House of Commons. Vol. 564, col. 901.

[94] Gapes, M. (2013, May 20) House of Commons. Vol. 563, col. 914.

[95] Baron Liddle of Carlisle (2012, May 17) House of Lords. Vol. 737, col. 571.

[96] Lord Howell of Guildford (2011, April 26) House of Lords. Vol. 727, col. 68.

\section{Appendix 2: America on Britain}

[1] Kerry, J. (2016, October 31) Remarks at the Benjamin Franklin House Medal for Leadership Ceremony. Benjamin Franklin House, London, UK. https://2009-2017.state.gov/secretary/remarks/2016/10/263891.htm

[2] Kerry, J. (2016, October 26) Remarks with Students at the University of Chicago's Institute of Politics. University of Chicago, Chicago, IL, USA. https://2009-2017.state.gov/secretary/remarks/2016/10/263655.htm

[3] Kerry, J. (October 20, 2016) Remarks with Saudi Arabian Foreign Minister Adel al-Jubeir after Their Meeting. Treaty Room, Washington DC, USA. https://2009-2017.state.gov/secretary/remarks/2016/10/263368.htm

[4] Carter, A. (2016, September 7) Remarks on the "U.S.-UK Alliance and the Future of the Principled International Order". Blavatnik School of Government, University of Oxford, UK.

https://www.defense.gov/News/Speeches/Speech-View/Article/936974/remarks-onthe-us-uk-alliance-and-the-future-of-the-principled-international-or/ 
[5] Kerry, J. (2016, July 21) Remarks at the Counter-ISIL Ministerial Meeting. Loy Henderson Auditorium, Washington DC, USA. https://2009-2017.state.gov/secretary/remarks/2016/07/260362.htm

[6] Kerry, J. (2016, June 27) Remarks with British Foreign Secretary Philip Hammond. Foreign and Commonwealth Office, London, UK. https://2009-2017.state.gov/secretary/remarks/2016/06/259121.htm

[7] Kerry, J. (2016, May 11) Remarks at Oxford Union. Oxford University, Oxford, UK. https://2009-2017.state.gov/secretary/remarks/2016/05/257109.htm

[8] Obama, B. (2016, April 25) Address to the Peoples of Europe. Hannover Messe Building, Hannover, Germany.

https://www.americanrhetoric.com/speeches/barackobama/barackobamaeuropehan over.htm

[9] Kerry, J. (2016, February 29) Remarks with German Foreign Minister Frank-Walter Steinmeier. Treaty Room, Washington DC, USA. https://2009-2017.state.gov/secretary/remarks/2016/02/253799.htm

[10] Obama, B. (2015, December 14) Update on Military Campaign against ISI. The Pentagon, VA, USA.

http://www.americanrhetoric.com/speeches/barackobama/barackobamacounterISIL update12-14-15.htm

[11] Carter, A. (2015, December 9) Statement on the Counter-ISIL Campaign before the Senate Armed Services Committee. Department of Defense, Washington DC, USA. http://www.defense.gov/News/Speeches/Speech-View/Article/633510/statement-on -the-counter-isil-campaign-before-the-senate-armed-services-committ

[12] Obama, B. (2015, December 6) Address to the Nation on Foreign and Domestic Counter-Terrorism Strategies. Oval Office, Washington DC, USA. https://obamawhitehouse.archives.gov/the-press-office/2015/12/06/address-nationpresident

[13] Kerry, K. (2015, December 3). Remarks at OSCE Ministerial Meeting. Kombank Arena, Belgrade, Serbia. https://2009-2017.state.gov/secretary/remarks/2015/12/250319.htm

[14] Kerry, J. (2015, December 2) Press Availability at NATO. Brussels, Belgium. https://2009-2017.state.gov/secretary/remarks/2015/12/250242.htm

[15] Obama, B. (2015, December 2) Statement by the President on Counter-ISIL Steps by the United Kingdom and Germany. The Oval Office, Washington DC, USA. https://obamawhitehouse.archives.gov/the-press-office/2015/12/03/statement-presi dent-counter-isil-steps-united-kingdom-and-germany

[16] Earnest, J. (2015, December 2) Press Briefing. The White House, Washington DC, USA.

https://obamawhitehouse.archives.gov/the-press-office/2015/12/03/press-briefing-p ress-secretary-josh-earnest-12215

[17] Obama, B. (2015, December 1) Paris Press Conference. Issy-les-Moulineaux, Paris, France.

http://www.americanrhetoric.com/speeches/barackobama/barackobamaparispressc onference.htm

[18] Kerry, J. (2015, October 28) Remarks at the Carnegie Endowment for International Peace. Washington DC, USA.

https://2009-2017.state.gov/secretary/remarks/2015/10/248937.htm

[19] Kerry, J. (2015, October 23) Remarks to the Press in Vienna. Imperial Hotel, Vien- 
na, Austria. https://2009-2017.state.gov/secretary/remarks/2015/10/248677.htm

[20] Work, R. (2015, September 10) Royal United Services Institute. Whitehall, London, UK.

http://www.defense.gov/News/Speeches/Speech-View/Article/617128/royal-unitedservices-institute-rusi

[21] Kerry, J. (2015, February 21) Remarks at Press Availability. US Embassy, London, UK. https://2009-2017.state.gov/secretary/remarks/2015/02/237747.htm

[22] Kerry, J. (2015, February 21) Remarks with U.K. Foreign Secretary Philip Hammond before Their Meeting. Carlton Gardens, London, UK. https://2009-2017.state.gov/secretary/remarks/2015/02/237738.htm

[23] Earnest, J. (2015, January 1) Press Gaggle by Press Secretary en Route Cedar Falls, IA, Aboard Air Force One.

https://obamawhitehouse.archives.gov/the-press-office/2015/01/14/press-gaggle-pre ss-secretary-josh-earnest-en-route-cedar-falls-ia-11415

[24] Kerry, J. (2014, November 18) Remarks with U.K. Foreign Secretary Philip Hammond before Their Bilateral Meeting. London, UK. https://2009-2017.state.gov/secretary/remarks/2014/11/234165.htm

[25] Kerry, J. (2014, October 28) Meeting with Embassy Ottawa Staff, Ottawa. US Embassy, Ottawa, Canada.

https://2009-2017.state.gov/secretary/remarks/2014/10/233473.htm

[26] Kerry, J. (2014, October 8) Remarks with U.K. Foreign Secretary Philip Hammond. Treaty Room, Washington DC, USA. https://2009-2017.state.gov/secretary/remarks/2014/10/232720.htm

[27] Earnest, J. (2014, September 26) Statement by the Press Secretary on United Kingdom and Belgian Parliament Decisions to Authorize Air Strikes Against ISIL. The White House, Washington DC, USA.

https://www.whitehouse.gov/the-press-office/2014/09/26/statement-press-secretaryunited-kingdom-and-belgian-parliament-decision

[28] Kerry, J. (2014, September 26) Remarks at Global Health Security Agenda Summit. Department of the Treasury, Washington DC, USA. https://2009-2017.state.gov/secretary/remarks/2014/09/232186.htm

[29] Earnest, J. (2014, September 26) Press Briefing by Press Secretary. The White House, Washington DC, USA.

https://www.whitehouse.gov/the-press-office/2014/09/27/press-briefing-press-secre tary-josh-earnest-9262014

[30] Kerry, J. (2014, September 24) Remarks at Syria Ministerial. UN Headquarters, New York City, NY, USA. https://2009-2017.state.gov/secretary/remarks/2014/09/232086.htm

[31] Hagel, C. (2014, September 18) Statement on Iraq, Syria, and ISIL before the House Armed Services Committee. Washington DC, USA. http://www.defense.gov/News/Speeches/Speech-View/Article/605610/statement-on -iraq-syria-and-isil-before-the-house-armed-services-committee

[32] Kerry, J. (2014, September 8) Remarks on the Formation of the Iraqi Government. State Department Debriefing Room, Washington DC, USA. https://2009-2017.state.gov/secretary/remarks/2014/09/231377.htm

[33] Obama, B. (2014, August 9) Statement by the President on Iraq. The White House, Washington DC, USA.

https://www.whitehouse.gov/the-press-office/2014/08/09/statement-president-iraq 
[34] Earnest, J. (2014, July 22) Daily Briefing by the Press Secretary. The White House, Washington DC, USA.

https://obamawhitehouse.archives.gov/the-press-office/2014/07/22/daily-briefing-p ress-secretary-josh-earnest-072214

[35] Kerry, J. (2014, June 23) Removal of Declared Chemical Materials from Syria. Washington DC, USA. https://2009-2017.state.gov/secretary/remarks/2014/06/228302.htm

[36] Kerry, J. (2014, May 28) Interview with Chuck Todd of MSNBC’s The Daily Rundown. Washington DC, USA. https://2009-2017.state.gov/secretary/remarks/2014/05/226598.htm

[37] Kerry, J. (2013, December 17) Remarks with Philippine Foreign Secretary Albert del Rosario. Department of Foreign Affairs, Manila, Philippines. https://2009-2017.state.gov/secretary/remarks/2013/12/218835.htm

[38] Obama, B. (2013, September 10) Address to the Nation on U.S. Military Action in Syria. The White House, Washington DC, USA.

https://obamawhitehouse.archives.gov/the-press-office/2013/09/10/remarks-preside nt-address-nation-syria

[39] Kerry, J. (2013, September 9) Remarks with United Kingdom Foreign Secretary Hague. United Kingdom Foreign and Commonwealth Office, London, UK. https://2009-2017.state.gov/secretary/remarks/2013/09/213956.htm

[40] Earnest, J. (2013, August 29) Press Briefing by Principal Deputy Press Secretary. The White House, Washington DC, USA.

https://www.whitehouse.gov/the-press-office/2013/08/29/press-briefing-principal-d eputy-press-secretary-josh-earnest-8292013

[41] Carney, J. (2013, August 27) Press Briefing by Press Secretary Jay Carney. The White House, Washington DC, USA.

https://obamawhitehouse.archives.gov/the-press-office/2013/08/27/press-briefing-p ress-secretary-jay-carney- 8272013

[42] Obama, B. (2013, May 13) Remarks by President Obama and Prime Minister Cameron of the United Kingdom in Joint Press Conference. The White House, Washington DC, USA.

https://obamawhitehouse.archives.gov/the-press-office/2013/05/13/remarks-preside nt-obama-and-prime-minister-cameron-united-kingdom-joint-

[43] Carney, J. (2013, May 8) Press Briefing by Press Secretary Jay Carney and Chief Technology Officer Todd Park. The White House, Washington DC, USA.

https://obamawhitehouse.archives.gov/the-press-office/2013/05/08/press-briefing-p ress-secretary-jay-carney-and-chief-technology-officer-t

[44] Carney, J. (2013, April 29) Press Briefing by Press Secretary Jay Carney. The White House, Washington DC, USA.

https://obamawhitehouse.archives.gov/the-press-office/2013/04/29/press-briefing-p ress-secretary-jay-carney-04292013

[45] Carney, J. (2013, June 4) Press Briefing by Press Secretary Jay Carney. The White House, Washington DC, USA.

https://obamawhitehouse.archives.gov/the-press-office/2013/06/04/press-briefing-p ress-secretary-jay-carney-642013

[46] Carney, J. (2012, March 15) Press Briefing by Press Secretary Jay Carney. The White House, Washington DC, USA.

https://obamawhitehouse.archives.gov/the-press-office/2012/03/15/press-briefing-p ress-secretary-jay-carney-3152012 
[47] Obama, B. (2012, March 14) Remarks by President Obama and Prime Minister Cameron of the United Kingdom in a Joint Press Conference. The White House, Washington DC, USA.

https://obamawhitehouse.archives.gov/the-press-office/2012/03/14/remarks-preside nt-obama-and-prime-minister-cameron-united-kingdom-joint- 